Bąkowski P., Cisowski P., Rubczak S., Wolff-Stefaniak M., Bąkowska A., Piontek T. Results of biomechanical isokinetic evaluation of patients after achilles tendon percutaneous suture. Issue Rehabil. Orthop. Neurophysiol. Sport Promot. 2017; 21: 31-38 DOI: 10.19271/ IRONS-00050-2017-21

\section{RESULTS OF BIOMECHANICAL ISOKINETIC EVALUATION OF PATIENTS AFTER ACHILLES TENDON PERCUTANEOUS SUTURE \\ Paweł Bąkowski ${ }^{1}$ \\ Paweł Cisowski ${ }^{1}$ \\ Szymon Rubczak ${ }^{1}$ \\ Maria Wolff-Stefaniak ${ }^{1}$ \\ Agata Bąkowska ${ }^{1}$ \\ Tomasz Piontek ${ }^{\mathbf{1}, \mathbf{2}}$ \\ ${ }^{1}$ Rehasport Clinic, Poznań, Poland \\ ${ }^{2}$ Department of Spine Disorders and Pediatric Orthopaedics, Poznań, Poland}

\section{SUMMARY}

\section{Introduction}

Achilles tendon is the strongest tendon in the whole body. After its injury, weaker flexor muscles are unable to fully compensate for its function. Therefore, a full recovery of calf muscles after treatment of injured Achilles tendon is of crucial importance. There are several methods of objective measurement of muscle strength, including isometric, isotonic or isokinetic methods with the use of a dynamometer.

\section{Aim}

The aim of the study was to present the results of biomechanical assessment of patients after percutaneous Achilles tendon suture.

\section{Material}

Twenty-eight patients which underwent percutaneous suture of injured Achilles tendon were enrolled in the study.

\section{Methods}

For isokinetic evaluation of patients, Biodex 3 dynamometer was used. Concentric and eccentric contraction strength of plantar foot flexors was evaluated. The following
WYNIKI BIOMECHANICZNEJ OCENY IZOKINETYCZNEJ PACJENTÓW PO PRZEZSKÓRNYM SZYCIU ŚCIĘGNA ACHILLESA

Paweł Bąkowski ${ }^{1}$

Paweł Cisowski ${ }^{1}$

Szymon Rubczak ${ }^{1}$

Maria Wolff-Stefaniak ${ }^{1}$

Agata Bąkowska ${ }^{1}$

Tomasz Piontek ${ }^{1,2}$

${ }^{1}$ Rehasport Clinic, Poznań, Poland

${ }^{2}$ Klinika Chorób Kręgosłupa i Ortopedii Dziecięcej, Uniwersytet Medyczny w Poznaniu

\section{STRESZCZENIE}

Wstęp

Ścięgno Achillesa jest najmocniejszym ścięgnem w całym organizmie. Z tego względu, po jego uszkodzeniu, słabsze mięśnie zginaczy nie są w stanie zrekompensować jego funkcjonowania. Dlatego pełne odbudowanie siły mięśni łydki po leczeniu zerwanego ścięgna Achillesa jest niezwykle istotne. Istnieje wiele metod obiektywnego pomiaru siły mięśniowej, w tym w warunkach izometrycznych, izotonicznych lub izokinetycznych przy użyciu dynamometru.

\section{Cel}

Celem pracy było przedstawienie wyników biomechanicznej oceny izokinetycznej pacjentów po przezskórnym szyciu ścięgna Achillesa.

\section{Materiał}

W badaniu wzięło udział 28 pacjentów operowanych technika przezskórnego szycia uszkodzonego ścięgna Achillesa.

\section{Metody}

Do oceny izokinetycznej pacjentów zastosowano dynamometr Biodex 3. Badano siłę skurczu koncentrycznego i ekscentrycznego. Oceniano parametry prędkościowo-siłowe 
muscle parameters were assesed at $30^{\circ} / \mathrm{s}$ and $90 \%$ s of angular velocity: absolute peak torque and its relation to the body weight, mean power and total work of flexor muscles of ankle joints. In addition, the circumference of the crus was measured.

\section{Results}

The results of muscle strength tests showed an asymmetry of $2 \%$ to $8 \%$ in favor of the operated limb. There was a decrease in the absolute strength of the operated limb by about $2 \%$. The median circumference of the lower nonoperated limb was $1.5 \mathrm{~cm}$ greater than the median circumference of the operated limb. No correlation was found between the crus circumference value and the isokinetic test results.

\section{Conclusions}

There are no statistically significant differences in the isokinetic scores between the operated and nonoperated limbs in patients after percutaneous Achilles tendon suture. There is no correlation between the lower leg circumference and isokinetic test results. Percutaneous Achilles tendon suture restores Achilles tendon function.

Keywords: Achilles tendon injury, muscle contraction force, isokinetic tests, Biodex

Date received: 1st November 2017

Date accepted: 21st November 2017

\section{Introduction}

The gastrocnemius and soleus calf muscles which form the Achilles tendon are considered the strongest plantar foot flexors. With the proper function of these muscles, standing on toes and raising the heel off the ground is possible during walking, jogging or jumping. In case of their dysfunction mięśni przy prędkościach kątowych $30^{\circ}$ s i $90^{\circ}$ s: bezwzględną szczytową wartość maksymalnego momentu siły jak i w stosunku do masy ciała, średnią moc i całkowitą pracę zginaczy stawu skokowego. Dodatkowo, wykonywano pomiar obwodu podudzia.

\section{Wyniki}

Wyniki w testach izokinetycznych w aspekcie zdolności wytrzymałościowych mięśni wskazywały na asymetrię od 2\% do $8 \%$ na korzyść kończyny operowanej. Zauważono obniżenie bezwzględnych parametrów siłowych kończyny operowanej o około $2 \%$. Mediana obwodów podudzia kończyny nieoperowanej była o 1,5 cm większa od średniej obwodów kończyny operowanej. Nie obserwowano korelacji pomiędzy wartością obwodu podudzia a wynikami testów izokinetycznych.

\section{Wnioski}

Brak istotnej statystycznie różnicy w wynikach testów izokinetycznych pomiędzy kończyną operowaną i nieoperowaną u pacjentów po przezskórnym szyciu ścięgna Achillesa. Brak korelacji pomiędzy obwodem podudzia a wynikami testów izokinetycznych. Przezskórne szycie ścięgna Achillesa przywraca funkcję ścięgna Achillesa.

Słowa kluczowe: uszkodzenie ścięgna Achillesa, siła skurczu mięśniowego, testy izokinetyczne, Biodex

Data otrzymania: 1 listopada 2017

Data zaakceptowania: 21 listopada 2017

or Achilles tendon dysfunction, standing on toes is not possible and walking is very difficult. This is due to the fact that strength of the remaining flexor muscles (tibialis posterior, flexor digitorum longus, flexor hallucis longus) is not sufficient for raising the bodyweight on the toes (Kendall and 
Kendall 1949). That is why it is of special importance to fully rebuild the calf muscles after ruptured Achilles tendon treatment.

The standardization of methods of muscle strength measurements was initiated in 1912 by Dr. Robert Lovett in patients with neurological disorders (Bochenek and Reicher 2002), 6 degrees of muscle strength were then distinguished. The application of Lovett's muscle strength scale, however, presents some limitations. Most importantly, the result depends largely on the researcher and the repeatability of the test is much lower than the objective methods. In some cases, especially with small muscle defects, this method is insufficiently sensitive (Gavies 1992). Testing can only be carried out under static conditions, which is a limitation in the examination of patients during sport activities.

The objective methods of measuring muscle strength require the use of dynamometers. Muscle strength measurements are performed under isometric, isotonic or isokinetic conditions, depending on the nature of the exercise.

An isokinetic study is characterized by a dynamic examination of the muscle contraction at constant angular velocity. The dynamometer constantly calculates and applies the appropriate resistance, which contrasts with the generated muscle contraction. This allows for working with the maximum load over the entire range of joint motion. The variability of a resistance given is critical in this assessment, due to varying working conditions of the muscle. Depending on the length of the muscle (joint setting) and its tension, the conditions to achieve maximum contraction also change. The dynamometer records the values of the peak torque and the corresponding settings in the joint. In this way, it is possible to measure the maximal force generated by the examined muscle group. The unquestionable advantage of isokinetic dynamometers is a variable resistance that never exceeds patient's abilities (pain, discomfort, motion restriction, etc.) (Davies 1992; Ciemniewska-Gorzela 2010). An additional advantage of isokinetic dynamometers is a measurement of the power, endurance and work performed by the examined muscles (Davies 1992; Ciemniewska-Gorzela 2010). A certain limitation of isokinetic testing is a need for non-functional and strictly defined positions."

\section{Aim}

The aim of the study was to present the results of biomechanical assessment of patients after percutaneous Achilles tendon suture.

\section{Material}

28 patients, aged from 19 to 61 years old, with documented transcutaneous surgical treatment of Achilles tendon injury were enrolled in the study. Patients were operated in two clinics in Poznań in years 2011 2015. All patients were operated with the same surgical technique. The median age was 41 y. o. ( \pm 6.5 years). The mean time from the surgery to the evaluation was 34 ( \pm 10.0 ) months (from 12 to 57 months). Left Achilles tendon was damaged in 20 cases, the right one - in 8 cases.

\section{Methods}

Isokinetic evaluation of patients was carried out using a Biodex 3 device. Biodex is a device for objective evaluation of muscle strength, equipped with an armchair and a dynamometer adjustable in 3 planes, which allows testing of various muscle groups.

The tests were performed in a prone position, with a straight line between the hip and knee joint. The tested extremity was attached to the Biodex 3 through velcro straps to increase its stability (Figure 1). Before each attempt, the patient was instructed how to perform the motion. At each stage, a starting position of the examined extremity was set to the intermediate position (dorsiflexion of 0 degrees). 


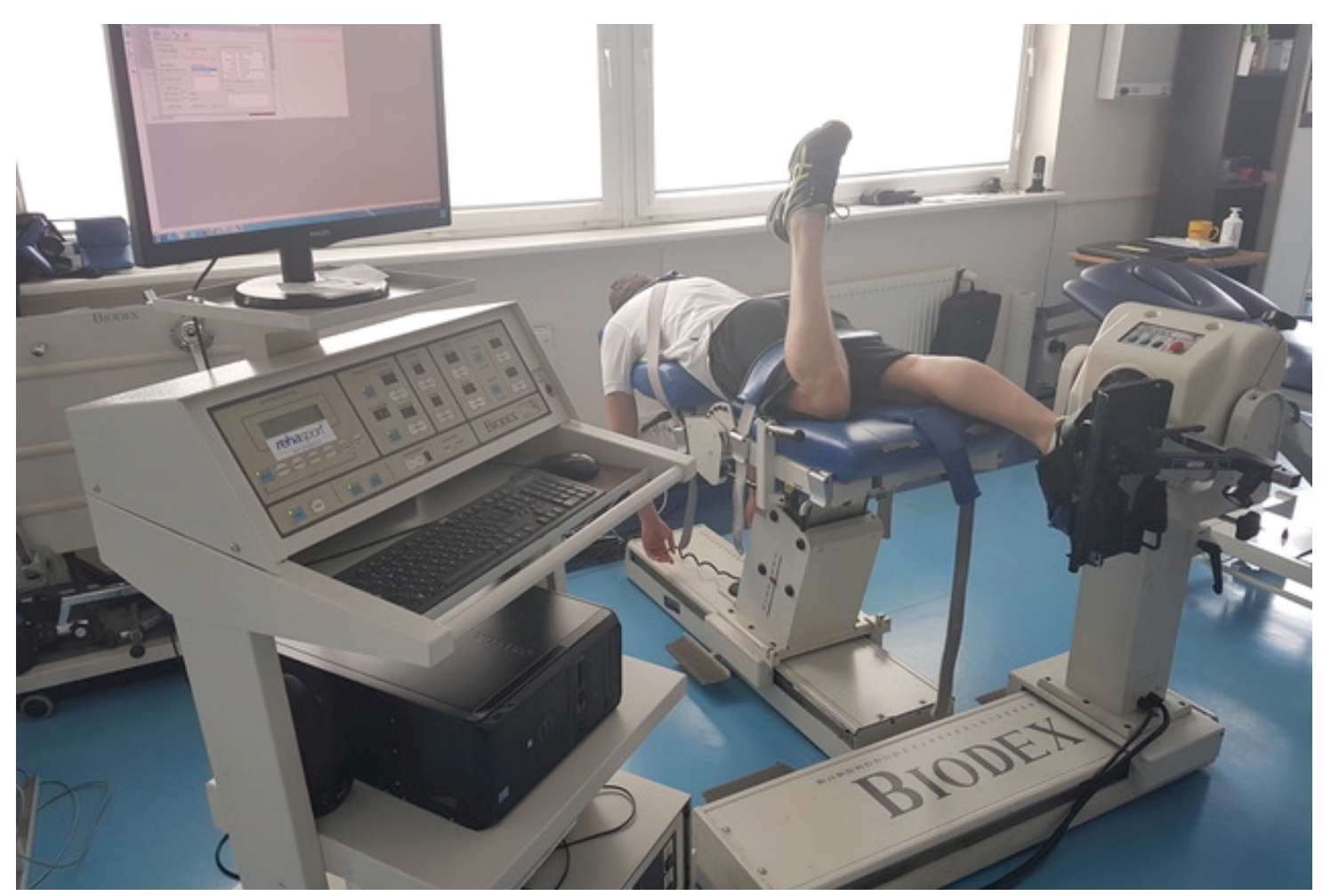

Figure 1. Patient's position performing isokinetic tests.

In the first stage, a both concentric and eccentric strenght of plantar flexors was measured. This stage consisted of 5 attempts for each limb at a velocity of 30 degrees/second. The purpose of this stage was to determine the peak torque of muscles from the back of the lower leg. In the next step, the angular velocity was set to 90 degrees/second, and this test determined the endurance of the studied muscle group. At this stage, patients performed 15 movements in plantar and dorsal flexion.

The following strength and endurance muscle parameters were evaluated at angular velocities of $30^{\circ} / \mathrm{s}$ and $90^{\circ} / \mathrm{s}$ :

- Peak Torque (PkTrq) of flexor muscles of ankle joint - The maximum torque value at any time during the test. It shows the maximum muscle strength of the studied muscle group (Davies 1992; Ciemniewska-Gorzela 2010).

- Peak value of maximal torque of flexor muscles of ankle joint in relation to the body weight (PkTrq/Weight), expressed in [\%] - the peak torque factor in relation to the body weight. This factor very well describes the functional capacity of the patient and is one of the best factors in determining the effectiveness of rehabilitation. Statistical analysis makes it easier to compare patients with different body weights (Davies 1992; Ciemniewska-Gorzela 2010).

- Average power of flexor muscles of ankle joint - the ratio of the total work value to the time of the work performed. This parameter describes how fast the muscles can generate the maximum torque, thus determining muscle capacity for rapid and effective action, which is particularly important in the clinical aspects of injury prevention (Davies 1992; Ciemniewska-Gorzela 2010; Carvalho et al. 2016).

- Total work of flexor muscles of ankle joint during the test - the value of the entire work performed during all repetitions in one test. This parameter determines the ability of a given muscle group to maintain the highest possible torque in a given time. The value of total work is affected by the range of motion in the joint - if it is limited on one side, the 
value of the total work, despite the same peak torque, will be lower. This factor is used in assessing the effectiveness of rehabilitation for full recovery of muscle groups (Davies 1992; Ciemniewska-Gorzela 2010).

- Percentage of the peak torque of the concentric and eccentric strenght (CON/ ECC Ratio\%) - indicates the correct or disturbed balance between the concentric and eccentric strength groups, what ensures the dynamic stabilization of the joint and reduces the risk of injury (Carvalho et al. 2016).

In addition, measurements of the crus circumference at its widest point in the standing position was performed (with $0.5 \mathrm{~cm}$ accuracy).

\section{Statistical analysis and bioethics}

Statistical analysis of the results was performed in the R environment. The level of statistical significance was set at $\mathrm{p}<0.05$. A statistical analysis of the differences in objective measurements was performed for the healthy and operated lower limb. Wilcoxon labeled tests were used.

This study was approved by the Bioethical Committee of the Regional Medical Council affiliated within Wielkopolska Izba Lekarska (opinion no. 191/2015, dated at 16.12.2015). All participants were informed about the objectives and scope of the study and signed the consent to participate in the study.

\section{Results}

Table 1 shows the results of isokinetic tests for the nonoperated and operated limb. A comparative analysis of the isokinetic test results for the nonoperated and operated limb was performed. There were no statistically significant differences for any isokinetic tests ( $p>0.05$ for each test).

Values are presented as mean \pm standard deviation. The minimum and maximum values are given in brackets.

The largest difference observed in the strength parameters was $36 \%$ (181 Nm of the peak torque for nonoperated limb versus $117 \mathrm{Nm}$ for the operated limb). The smallest difference was $-27 \%$, which reflects higher values of the strength parameters for the operated limb (196 Nm of the peak torque for nonoperated limb and $266 \mathrm{Nm}$ for the operated limb).

The highest recorded difference in endurance parameters was 25\% (1226 J in concentric contraction of nonoperated limb and $923 \mathrm{~J}$ of the operated limb). The smallest difference recorded was $-56 \%$, which meant lower values of endurance

Table 1. Isokinetic test results for nonoperated and operated limb.

\begin{tabular}{|c|c|c|c|}
\hline Parameter & $\begin{array}{l}\text { Nonoperated } \\
\text { limb }\end{array}$ & $\begin{array}{l}\text { Operated } \\
\text { limb }\end{array}$ & $\mathbf{p}$ \\
\hline Peak torque concentric contraction [Nm] & $\begin{array}{l}180.3 \pm 68.3 \\
(66.6 \pm 322.9)\end{array}$ & $\begin{array}{l}179.8 \pm 67.9 \\
(52.5 \pm 303.9)\end{array}$ & 0.7366 \\
\hline Peak torque eccentric contraction [Nm] & $\begin{array}{l}189.7 \pm 69.4 \\
(88 \pm 329.1)\end{array}$ & $\begin{array}{l}185.8 \pm 70.9 \\
(78 \pm 315.8)\end{array}$ & 0.8527 \\
\hline $\begin{array}{l}\text { Peak torque/bodyweight concentric } \\
\text { contraction }[\mathrm{Nm} / \mathrm{kg}]\end{array}$ & $\begin{array}{l}2.1 \pm 0.7 \\
(0.8 \pm 3.8)\end{array}$ & $\begin{array}{l}2.1 \pm 0.7 \\
(0.7 \pm 3.6)\end{array}$ & 0.6528 \\
\hline $\begin{array}{l}\text { Peak torque/bodyweight eccentric } \\
\text { contraction }[\mathrm{Nm} / \mathrm{kg}]\end{array}$ & $\begin{array}{l}2.2 \pm 0.7 \\
(1.0 \pm 3.9)\end{array}$ & $\begin{array}{l}2.1 \pm 0.7 \\
(0.9 \pm 3.8)\end{array}$ & 0.7861 \\
\hline Work concentric contraction [j] & $\begin{array}{l}699.6 \pm 383.7 \\
(62.9 \pm 1328)\end{array}$ & $\begin{array}{l}762.2 \pm 351.0 \\
(49.2 \pm 1613)\end{array}$ & 0.1014 \\
\hline Work eccentric contraction [j] & $\begin{array}{l}893.9 \pm 414.5 \\
(211.6 \pm 1762)\end{array}$ & $\begin{array}{l}949.1 \pm 409.8 \\
(285.3 \pm 1768)\end{array}$ & 0.2099 \\
\hline Power concentric contraction [w] & $\begin{array}{l}62.1 \pm 26.5 \\
(9.3 \pm 98.1)\end{array}$ & $\begin{array}{l}67.5 \pm 25.4 \\
(5.3 \pm 111.3)\end{array}$ & 0.15 \\
\hline Power eccentric contraction [w] & $\begin{array}{l}66.3 \pm 28.0 \\
(15.1 \pm 137)\end{array}$ & $\begin{array}{l}68.2 \pm 28.8 \\
(23.2 \pm 145.6)\end{array}$ & 0.6338 \\
\hline Con/Ecc Ratio [\%] & $\begin{array}{l}1.1 \pm 0.0 \\
(0.88 \pm 1.3)\end{array}$ & $\begin{array}{l}1.0 \pm 0.1 \\
(0.6 \pm 1.4)\end{array}$ & 0.8325 \\
\hline
\end{tabular}


parameters for the nonoperated limb (187 J) when compared to operated limb (422 J).

The measurements of the crus circumference are shown in Table 2. The difference in the circumference was statistically significant $(p=0.00012)$. The median of the nonoperated limb circumference was $1.5 \mathrm{~cm}$ higher than the median circumference of the operated limb $(38.5 \mathrm{~cm}$ and $37.0 \mathrm{~cm}$, respectively). The largest difference in the circumference of the lower leg was $3.0 \mathrm{~cm}$ (observed in 6 patients). The smallest difference in the circumference of the lower leg was $-1.5 \mathrm{~cm}$, which reflects a higher crus circumference in the operated limb (observed in 2 patients). Three patients did not have a difference in the crus circumference. This means that reduction of the crus circumference in the operated limb concerned 23 of 28 patients ( $82 \%$ ). endurance parameters of the examined muscle group. One of the limitations of the above testing when compared to the functional tests, is an access to the specialized equipment.

The isokinetic scores for muscular endurance in the studied group of patients indicate an asymmetry of $2 \%$ to $8 \%$ in favor of the operated limb. In addition, a decrease in the absolute strength of the operated limb was observed by about $2 \%$. These results may indicate a good recovery of muscle capacity to generate strength with good restoration of endurance parameters.

Similar observations on muscle strength reduction in isokinetic tests were also reported by other authors (Carter et al. 1992; Chan et al. 2011). Rosso et al. (Rosso et al. 2015), in a group of 52 patients at least 3 years after surgery, reported a 13\% strength

Tabela 2. The results of the crus circumference measurements $[\mathrm{cm}]$ of nonoperated and operated limb.

\begin{tabular}{llllll}
\hline & Minimum & Median & Maximum & Standard deviation & Standard error \\
\hline Nonoperated limb & 33.5 & 38.5 & 42 & 2.18 & 0.41 \\
\hline Operated limb & 30.5 & 37 & 42 & 2.80 & 0.53 \\
\hline
\end{tabular}

No statistically significant correlation was found between the crus circumference and the isokinetic tests results.

\section{Discussion}

The most important finding of the study was lack of statistically significant differences in the isokinetic test scores between the operated and nonoperated limbs in patients after percutaneous Achilles tendon suture. An additional conclusion is that there is no correlation between the lower limb circumference and the isokinetic test results.

Isokinetic tests allow to assess the ability of the muscles to perform work in postoperative rehabilitation of patients. The dynamometer can be used in reliable and repetitive manner (Costa et al. 2006; Moller et al. 2005; Keating and Will 2011) to determine the absolute values of strength and decrease in the operated limb compared with healthy ones. McNair (McNair et al. 2013) reported a difference of $20 \%$ in patients 6 months after surgery. This confirms Olsson's conclusions (Olsson et al. 2011) that a key period of patient improvement is the first 12 months after the surgery, where the potential for improvement exists. It is now well-recognized that the problem of muscle weakness after surgical treatment lies in the time of immobilization when permanent damage to muscle fibers occurs. 


\section{REFERENCES}

Bochenek, A., Reicher, M. Anatomia człowieka, Podręcznik dla studentów medycyny i lekarzy. 11th Ed. Warszawa: Wydawnictwo Lekarskie PZWL; 2002.

Carter, T.R., Fowler, P.J., Blokker, C. (1992) 'Functional postoperative treatment of Achilles tendon repair.' Am J Sports Med., 20(4), pp. 459-462.

Carvalho, A., Brown, S., Abade, E. (2016) 'Evaluating injury risk in first and second league professional Portuguese soccer: Muscular strength and asymmetry.' J Hum Kinet., 50(2), pp. 19-26.

Ciemniewska-Gorzela, K. Funkcja stawu kolanowego po rekonstrukcji więzadła $k r$ zyżowego przedniego. Rozprawa doktorska. Uniwersytet Medyczny, Poznań, 2010.

Chan, A.P., Chan, Y.Y., Fong, D.T., Wong, P.Y., Lam, H.Y., Lo, C.K., Yung, P.S., Fung, K.Y., Chan, K.M. (2011) 'Clinical and biomechanical outcome of minimal invasive and open repair of the Achilles tendon.' Sports Med Arthrosc Rehabil Ther Technol., 3(1), pp. 32. Costa, M.L., MacMillan, K., Halliday, D., Chester, R., Shepstone, L., Robinson, A.H., Donnel, S.T. (2006) 'Randomised controlled trials of immediate weight-bearing mobilisation for rupture of the tendo Achillis.' J Bone Joint Surg., 88(1), pp. 69-77.

Davies, G. A compendium of isokinetics in clinical usage and rehabilitation techniques. 4th Ed. Onalaska: WI: S\&S Publishers; 1992. Keating, J.F., Will, E.M. (2011) 'Operative versus non-operative treatment of acute rupture of tendo Achillis: a prospective randomised evaluation of functional outcome.' J Bone Joint Surg Br., 93(8), pp. 1071-1078. Kendall, H., Kendall, F. Muscles testing and function. Baltimore: Williams and Wilkins; 1949.

McNair, P., Nordez, A., Olds, M., Young, S.W., Cornu, C. (2013) 'Biomechanical properties of the plantar flexor muscle-tendon complex 6 months post-rupture of the Achilles tendon.' J Orthop Res., 31(9), pp. 1469-1474. Moller, M., Lind, K., Styf, J., Karlsson, J. (2005) 'The reliability of isokinetic testing of the ankle joint and a heel-raise test for endurance.' Knee Surg Sports Traumatol Arthrosc., 13(1), pp. 60-71.

Olsson, N., Nilsson-Helander, K., Karlsson, J., Eriksson, B.I., Thomee, R., Faxen, E., Silbernagel, K.G. (2011) 'Major functional deficits persist 2 years after acute Achilles tendon rupture.' Knee Surg Sports Traumatol Arthrosc., 19(8), pp. 1385-1393.

Rosso, C., Buckland, D.M., Polzer, C., Sadoghi, P., Schuh, R., Weisskopf, L., Vavken, P., Valderrabano, V. (2015) 'Long-term biomechanical outcomes after Achilles tendon ruptures.' Knee Surg Sports Traumatol Arthrosc., 23(3), pp. 890-898. 
Author reported no source of funding. Author declared no conflict of interest.

Author responsible for correspondence: Pawet Bakowski

Rehasport Clinic

Górecka 30

60-201 Poznań

Poland

pawel.bakowski@rehasport.pl
Autorzy nie zgłosili źródła finansowania.

Autorzy nie deklarowali konfliktu interesów.

Autor odpowiedzialny za korespondencję:

Pawet Bakowski

Rehasport Clinic

ul. Górecka 30

60-201 Poznań

Polska

pawel.bakowski@rehasport.pl 